\title{
Utilisation of a Portable Electronic Nose, NeOse Pro, to Follow the Microbial Fermentation of a Yoghurt
}

\author{
Yann Demarigny ${ }^{1}$, Elodie Legrand ${ }^{1}$, Julia Sanchez1, Arnaud Hallier ${ }^{1}$, Nathalie Laurent ${ }^{1}$, \\ Sami Slimani2 ${ }^{2}$, Thierry Livache ${ }^{2}$, Daniel Picque ${ }^{3}$ \\ ${ }^{1}$ ISARA Lyon, Equipe AgroLab, BioDyMIA (Bioingénierie et Dynamique Microbienne aux Interfaces Alimentaires), ISARA, \\ Agrapôle, Lyon, France \\ ${ }^{2}$ Aryballe Technology, Grenoble, France \\ ${ }^{3}$ INRA, GMPA, AgroParis Tech, Paris, France \\ Email: *ydemarigny@isara.fr
}

How to cite this paper: Demarigny, Y., Legrand, E., Sanchez, J., Hallier, A., Laurent, N., Slimani, S., Livache, T. and Picque, D. (2021) Utilisation of a Portable Electronic Nose, NeOse Pro, to Follow the Microbial Fermentation of a Yoghurt. Food and $\mathrm{Nu}$ trition Sciences, 12, 90-105.

https://doi.org/10.4236/fns.2021.121008

Received: December 14, 2020

Accepted: January 25, 2021

Published: January 28, 2021

Copyright $\odot 2021$ by author(s) and Scientific Research Publishing Inc. This work is licensed under the Creative Commons Attribution International License (CC BY 4.0).

http://creativecommons.org/licenses/by/4.0/

\section{(c) (i) Open Access}

\begin{abstract}
Yoghurt is fermented milk which results from the exclusive action of Lactobacillus delbrueckii subsp bulgaricus and Streptococcus thermophilus. However, a disruption of the bacterial growth can lead to significant industrial losses. Currents monitoring methods, based on the checking of the $\mathrm{pH}$ during the fermentation step are not always satisfactory. The NeOse Pro system, a portable electronic nose, is a mean to obtain immediately aromatic profiles. In this work, we applied this technology to the yoghurt ecosystem, a highly hydrated product. The profiles obtained allowed us to discriminate yoghurts before and after fermentation. In detail, the discrepancy between the two bacteria cultured alone was slight. It was also the case when we compared different initial bacterial ratios. However, two different mixes of bacteria led to clearly distinguishable profiles. A GC/MS analysis performed on products fermented $7 \mathrm{~h}$ allowed us to explain the detection of acetaldehyde by the stimulation of some captors of the apparatus. NeOse Pro is so convenient to study the fermentation of yogurt.
\end{abstract}

\section{Keywords}

NeOse Pro, Yoghurt, GC/MS, Aroma

\section{Introduction}

Fermented milks, and among them, yoghurts, are ancient foods that appeared at the same period as the domestication of dairy animals (around 8000 years ago). 
It allowed people to preserve milk over long periods [1]. Even if the process is ancient, the benefit of fermented milk for human food and health was only revealed at the beginning of the twentieth century. Eli Metchnikoff, considered as the inventor of the term "probiotics", observed a link between the longevity of people from central Europe and their consumption of fermented milks. He suggested that lactobacilli-the main bacterial species involved in the fermentation step-could prevent from "fouling" in the large intestine and so extend life [2] [3] [4]. The link between yoghurt eating and the improvement of the human microbiota was confirmed thereafter. But the democratization of the fridge at the family scale after the second world war certainly contributed to the increase of yoghurt consumption.

The yoghurt regulations vary from country to country. In France, yoghurt has to contain a minimum of $7 \mathrm{log}(\mathrm{cfu}) / \mathrm{g}$ of viable bacteria and at least $0.6 \%$ of lactic acid until the end of its shelf life. The starter used is limited to the commensal action of Streptococcus thermophilus and Lactobacillus delbrueckii subsp. bulgaricus (respectively designed thereafter as St thermophilus, or ST, and Lb bulgaricus, or LB). The addition of a third bacterium, Bifidobacterium for instance, prohibits the name of yoghurt.

During the fermentation step, St thermophilus and Lb bulgaricus are mainly responsible for the acidification of the milk. Both bacteria transform lactose into lactic acid, which leads to the progressive solubilisation of micellar calcium phosphate and finally to the complete disruption of casein micelles. This is the first step of the gel formation. Lb bulgaricus produces the D-lactic acid isomer, whereas St thermophilus produces L-lactic acid. The two bacteria also contribute significantly to the aromatic balance of the yogurt via the production of aroma compounds (mainly diacetyl and acetaldehyde), and to its texture and its viscosity. In this latter case, they can release exopolysaccharides (EPS) in the medium which leads to the jellification of the clotted milk. Generally, St thermophilus is a strong EPS producer contrarily to $L b$ bulgaricus. The typical flavour of yoghurt relies on its sour taste (explained by lactic acid accumulation) and on the presence of acetaldehyde, the main yogurt flavour component. Frequently, St thermophilus also produces acetone and diacetyl from citric acid [5]. During the fermentation step, St thermophilus is supposed to start first, followed thereafter by $L b$ bulgaricus (i.e. when the $\mathrm{pH}$ reaches 5 to 5.2 ). Consequently, the construction of the specific yogurt aroma depends on the successive growths of the two bacteria seeded in appropriate proportions, frequently at a ratio of 99:1 (St thermophilus: Lb bulgaricus).

At present time, analyses made at the industrial scale during the yogurt production are only based on the $\mathrm{pH}$ measure; because it is easy and quick to do and automatized. However, $\mathrm{pH}$ is a global parameter which fails to translate the dynamics of the two bacteria if, for instance, we specifically focus on the aroma construction. Technical means available to follow aroma-GC/MS for instance-are not convenient at the plant scale. Aryballe, an innovating start-up 
located in Grenoble (France), developed a portable aroma analyser called NeOse Pro. This apparatus mimics the behaviour of the volatile molecules when they are caught by the sensory cells of the nose. In this work, we were challenged to test the efficiency of the NeOse Pro in a humid environment, i.e. the yogurt ecosystem. This article reports the results obtained when different yogurts are made and compared according to the NeOse Pro technic linked with GC/MS analyse.

\section{Materials and Methods}

\subsection{Bacterial Strains}

Two mix of yogurt lactic acid bacteria coming from the lab collection were used in this study, N1 and N2. Both included one strain of Streptococcus thermophilus (STN1, STN2) and one strain of Lactobacillus delbrueckii subsp bulgaricus (LBN1, LBN2). The four strains were stored at $-80^{\circ} \mathrm{C}$ in a medium containing $0.4 \mathrm{~mL}$ of an overnight culture $\left(42^{\circ} \mathrm{C}\right), 0.4 \mathrm{~mL}$ of sterilized broth and $0.4 \mathrm{~mL}$ of glycerol (30\%, SIGMA). The broths used culture the bacteria were either M17 (BIOKAR) for streptococci or MRS (BIOKAR) for lactobacilli.

\subsection{Sample Preparation}

During the course of this experiment, we inoculated milks with different mix of bacteria. The cow milks used systematically originated from the same batch and from two different origins. The first type of milk was purchased from OXOID. Before use, this milk powder was reconstituted $(10 \%)$ and sterilized $\left(110^{\circ} \mathrm{C}, 10\right.$ min). The second type of milk was half-skimmed and microfiltered; it was bought in a supermarket (Marguerite). Each mix included one strain of ST and one strain of LB. N1 and N2 bacteria were never mixed together. For each bacterial association (N1 or N2), three ratios were tested: 50:50, 99:1 and 1:99 (ST:LB). The standardization of each ratio was made according to the methodology already described by Demarigny et al. (1994) [6]. Each bacterium was cultured at $42^{\circ} \mathrm{C}$ in milk. The $\mathrm{pH}$ and the bacterial levels were followed from time to time and the corresponding curves were drawn. To adjust the initial ratio, the two bacterial strains were separately cultured in milk $\left(42^{\circ} \mathrm{C}\right)$ during one night. The measure of the $\mathrm{pH}$ of this preculture allowed us to calculate the volume to be added to reach the appropriate concentration in the experimental milk culture ( $1 \mathrm{~L}$, prepared as indicated above). In this study, all the cultures were standardized to start the fermentation steps at approximately $10^{6} \mathrm{cfu} / \mathrm{mL}$ $(\mathrm{LB}+\mathrm{ST}$, Table 1).

Table 1. Theoretical levels of inoculation for each bacterium following the ratio ST/LB aimed at; data are expressed in $\mathrm{cfu} / \mathrm{mL}$.

\begin{tabular}{cccc}
\hline Type of bacteria & $50: 50$ & $99: 1$ & $1: 99$ \\
\hline Streptococcus thermophilus (STN1, STN2) & $5.0 \times 10^{5}$ & $9.9 \times 10^{5}$ & $1.0 \times 10^{4}$ \\
Lactobacillus delbrueckii subsp bulgaricus (LBN1, LBN2) & $5.0 \times 10^{5}$ & $1.0 \times 10^{4}$ & $9.9 \times 10^{5}$ \\
\hline
\end{tabular}


After inoculation with the proper ratio, milks were incubated at $42^{\circ} \mathrm{C}$. The growth of the two bacterial strains and the $\mathrm{pH}$ of the medium were monitored over time. At initial time and after $7 \mathrm{~h}$, two samples were also taken for gas chromatography and mass spectrometry analysis (GC/MS) and NeOse Pro analysis.

Unless specified, all the experiments were made in triplicate.

\subsection{Bacterial Growths, Titritable Acidities and pH Dynamics}

$\mathrm{pH}$ was determined with a $\mathrm{pH}$-meter (HI 2211, pH/ORP Meter, Hanna instruments) on $10 \mathrm{~mL}$ of milk. The total titratable acidity (TTA) value was defined as the amount of a $0.1 \mathrm{~N} \mathrm{NaOH}$ solution required to reach a $\mathrm{pH}$-value of 8.5. The results were expressed in milliliters [7]. Bacterial levels were determined by colony enumeration on MRS (LB) or M17 plates (ST). Samples were first diluted in trypton salt (BIOKAR) before being spread on petri dishes.

\subsection{SPME/GC-MS Analysis}

Volatile compounds were analysed using the Solid-Phase Micro Extraction Gas-Chromatography technique (SPME/GC, 6890 Series GC System, Hewlett Packard), coupled with Mass-Spectrometry (MS, 5973 Mass Selective Detector, Hewlett Packard). Ten millilitres of supernatant were placed in a vial and heated at $42^{\circ} \mathrm{C}$ for $10 \mathrm{~min}$. SPME-fiber was conditioned at $270^{\circ} \mathrm{C}$ for $30 \mathrm{~min}$. Compounds were absorbed onto this fiber (SPME Fiber Assembly DVB/CAR/PDMS, Supelco, SIGMA) at $42^{\circ} \mathrm{C}$ for $30 \mathrm{~min}$. They were then desorbed and separated with the temperature gradient proposed by Aggelopoulos et al. (2014) [8]. Helium was used as the vector gas with a flow rate of $1 \mathrm{~mL} / \mathrm{min}$. Molecules were separated through a BPX 5 capillary column, $30 \mathrm{~m} \times 0.25 \mathrm{~mm}$ i.d. $\times 0.25 \mu \mathrm{m}, 5 \%$ diphenyl and 95\% dimethylpolysiloxane (Phenomenex, Le Pecq, France). They were identified using Chemstation software by spectra comparison with NIST 05 and NIST 98 libraries.

\subsection{NeOse Pro Measures}

The NeOse Pro apparatus was developed to mimic the sensory cells of the nose. Sixty-four sensors are fixed on a gold micro array. A fan sucks up the volatile molecules originating from the product analysed. These molecules interact with 64 peptides arrayed on the gold layer of an SPR imaging device optical sensor. The resulting interactions are monitored versus time as a change of reflectivity and are ploted as sensorgrams [9] [10].

The preparation of the NeOse Pro apparatus was made according to the preconisation of Aryballe.

Three replicates were made for each analysis. A blank was made with a flask identical to those used for the samples and containing $10 \mathrm{~mL}$ of water. The blank measure was performed before the first analysis and after any new test. The methodology was standardized as best as possible. For instance, the temperature of the samples was carefully controlled throughout the experiment. 
NeOse Pro measurements were made at different steps during the yoghurt fermentation (T0, T1, T2, T3, T4, T5, T6, T7, T8, T24 h). Experiments were carried out in reconstituted milk (OXOID, $10 \% \mathrm{w} / \mathrm{v}$ ), sterilized at $110^{\circ} \mathrm{C} / 10 \mathrm{~min}$, or in half skimmed microfiltered milk bought in supermarket.

\subsection{REP-PCR}

The extraction of total DNA was based on the method of Masco et al. (2003) [11]. An overnight broth culture (MRS for LB and M17 for ST) was centrifuged for $3 \mathrm{~min}$ at $13,000 \mathrm{rpm}$ at $4^{\circ} \mathrm{C}$. The supernatant was removed and the pellet re-suspended in $170 \mu \mathrm{L}$ of T1 buffer (Genomic DNA from tissue, MACHEREYNAGEL) and $20 \mu \mathrm{L}$ of a lysozyme solution $(0.1 \mathrm{mg} / \mu \mathrm{L})$ was added in an Eppendorf tube. The mixture was incubated for $30 \mathrm{~min}$ at $37^{\circ} \mathrm{C}$. $20 \mu \mathrm{L}$ of RNase (1 $\mathrm{mg} / \mathrm{mL}$ ), $30 \mu \mathrm{L}$ of proteinase $\mathrm{K}(1 \mathrm{mg} / \mathrm{mL}$ ) and $20 \mu \mathrm{L}$ of SDS (Sodium Dodecyl Sulfate) $10 \%$ were then added in each tube. Except when specified, all the chemicals used were from SIGMA. The mixture was left to incubate overnight at $37^{\circ} \mathrm{C}$ in a water bath. The day after, Eppendorf tubes were incubated for $45 \mathrm{~min}$ at $64^{\circ} \mathrm{C}$; then, $200 \mu \mathrm{L}$ of buffer B3 (Genomic DNA from tissue, MACHEREYNAGEL) were added. The tubes were then placed at $70^{\circ} \mathrm{C}$ for $10 \mathrm{~min} .600 \mu \mathrm{L}$ of CTAB (cetyltrimethylammonium bromide) were added. The tubes were incubated for $30 \mathrm{~min}$ at $64^{\circ} \mathrm{C}$ and $800 \mu \mathrm{L}$ of chloroform-isoamyl 24:1 ethanol were added. The tubes were then centrifuged during $5 \mathrm{~min}$ at 13,000 rpm and the upper phase was recovered in a clean collecting tube with an elution column. 210 $\mu \mathrm{L}$ of absolute ethanol were added; the tubes were centrifuged $1 \mathrm{~min}$ at 13,000 rpm. The collector tube was emptied and $500 \mu \mathrm{L}$ of BW buffer (Genomic DNA from tissue, MACHEREY-NAGEL) were added prior to another centrifugation (1 min at 13,000 rpm). The collector tube was emptied and $600 \mu \mathrm{L}$ of $\mathrm{B} 5$ buffer (Genomic DNA from tissue, MACHEREY-NAGEL) were added. The tubes were successively centrifuged $1 \mathrm{~min}$ and $3 \mathrm{~min}$ at 13,000 rpm, the collecting tube being emptied at the end of each centrifugation. The column was then placed in a $1.5 \mathrm{~mL}$ Eppendorf tube; $70 \mu \mathrm{L}$ of BE buffer (Genomic DNA from tissue, MACHEREY-NAGEL) preheated at $70^{\circ} \mathrm{C}$ were added. After a rest $5 \mathrm{~min}$ at room temperature, the tube was finally centrifuged twice for $1 \mathrm{~min}$ at 13,000 rpm.

The protocol followed for DNA amplification and migration was identical to the procedure already published by Masco et al. (2003) [11].

\subsection{Analysis of the Results}

Principle component analysis (PCA) and hierarchical cluster analysis (HCA) were performed using the XLStat software (Microsoft, 2016).

\section{Results}

\subsection{Microbial and pH Considerations}

In all the experiments, the ST on LB ratio was carefully standardized to be as 
closed as possible to the theoretical values aimed at (Table 1). The measured values obtained at the beginning of the fermentation steps are shown in Table 2. Whatever the ratios, the differences between theoretical and analytical ratios were small.

During the acidification step, the evolution of the $\mathrm{pH}$ was nearly identical irrespective of the mix of ST and LB used (N1 or N2) or the ratio $(1 / 99,50 / 50$, 99/1). In particular, if slight differences were occasionally observed at the beginning of the culture (less than $0.1 \mathrm{pH}$ unit), they disappeared rapidly. At the end, the $\mathrm{pH}$ was equivalent in all the cultures $( \pm 0.02)$.

\subsection{Comparison of NeOse Pro Profiles before and after Milk Fermentations}

This experiment was performed on half skimmed microfiltered milk. Two NeOse Pro measures were made, one just after the inoculation of the milk with one of the two mix of bacteria (STN1 + LBN1 or STN2 + LBN2) and the other at the end of the fermentation step $(\mathrm{T}=7 \mathrm{~h})$. Figure 1 shows an example of radar charts obtained after NeOse Pro analysis with the N1 bacterial mix. The radar chart sums up the normalized intensity values for the 64 sensors involved in the volatile molecule detection. Each graph is specific of the aromatic balance of each sample; as such, it is an image or a sign of the sample. As one can notice, the fermentation step led to a change in the aromatic profile of the milk as a consequence of the bacterial development. The same observations could be drawn from the study of the second mix (N2).

A principal component analysis was performed with the data obtained to build the radar charts shown on Figure 1 (Figure 2). Experiments were made in triplicate. The first axe of the PCA totalized $90.78 \%$ of the information inertia. It means that the discrepancy between non fermented and fermented milk ("yoghurt" on Figure 2) follows the first axe, confirming the difference of aroma profiles between the two states. As indicated above the same results were obtained with the second yogurt mix (N2, data not shown).

Table 2. Difference between theoretical and analytical values following the ratios aimed at. ST: St thermophilus, LB: Lactobacillus, N1, N2: mix of LB and ST. Each value is the mean of two measures. Microbial data are expressed in $\mathrm{cfu} / \mathrm{mL}$ and ratios in \%.

\begin{tabular}{cccccc}
\hline \multirow{2}{*}{$\begin{array}{c}\text { Bacteria mix and } \\
\text { ratio (ST/LB) }\end{array}$} & \multicolumn{2}{c}{ Theoretical values } & \multicolumn{2}{c}{ Analytical values } & Analytical ratios \\
\cline { 2 - 5 } & ST & LB & ST & LB & \\
\hline N1 50:50 & $5.0 \times 10^{5}$ & $5.0 \times 10^{5}$ & $6.0 \times 10^{5}$ & $7.5 \times 10^{5}$ & $44 / 56$ \\
N2 50:50 & $5.0 \times 10^{5}$ & $5.0 \times 10^{5}$ & $4.65 \times 10^{5}$ & $6.13 \times 10^{5}$ & $44 / 56$ \\
N1 1:99 & $1.0 \times 10^{4}$ & $5.9 \times 10^{5}$ & $3.0 \times 10^{3}$ & $2.0 \times 10^{5}$ & \\
N2 1:99 & $1.0 \times 10^{4}$ & $5.9 \times 10^{5}$ & $2.65 \times 10^{5}$ & $3.55 \times 10^{6}$ & \\
N1 99:1 & $5.9 \times 10^{5}$ & $1.0 \times 10^{4}$ & $4.0 \times 10^{6}$ & $1.74 \times 10^{5}$ & \\
N2 99:1 & $5.9 \times 10^{5}$ & $1.0 \times 10^{4}$ & $3.4 \times 10^{6}$ & $6.25 \times 10^{4}$ & 95.93 .1 \\
\hline
\end{tabular}




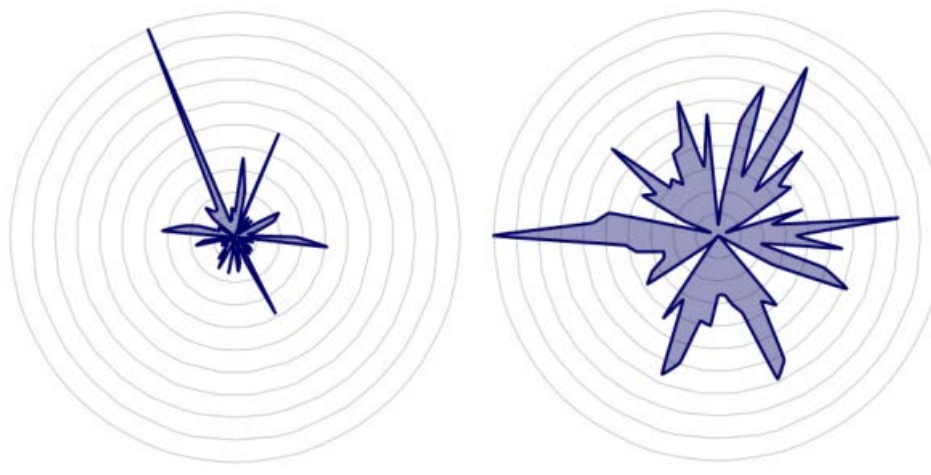

Figure 1. Example of radar charts obtained before (initial time) and after $(\mathrm{T}=7 \mathrm{~h})$ fermentation of the milk with the STN1/LBN1 mix. The data were gathered after a $7 \mathrm{~h}$ culture step at $42^{\circ} \mathrm{C}$.

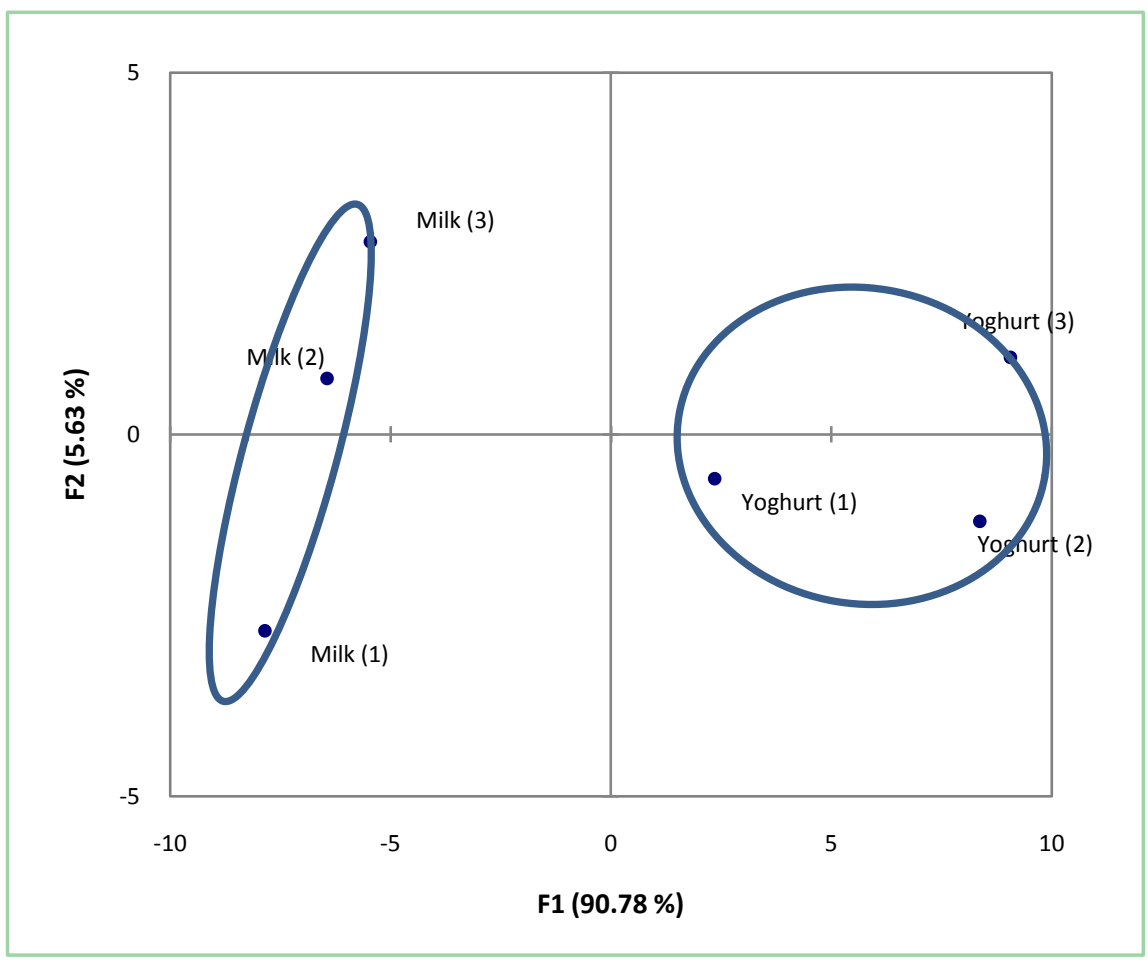

Figure 2. Principal Component Analysis (PCA) of NeOse Pro data obtained on milk before and after fermentation with the N1 yogurt mix. Number in brackets refer to the repetition.

\subsection{Comparison of NeOse Pro Profiles Obtained during Sterilized Milk Fermentations}

The sterilization of the milk led to the generation of empyreumatic compounds in high concentrations. These chemical products created a background signal which hided the volatile compounds released by the microbes, whatever the fermentation step. The initial NeOse Pro profile $(t=0)$ was so subtracted from the profiles obtained thereafter, the addition of the microorganisms at initial time being still ineffective. On this base, the profiles obtained after 1 and $2 \mathrm{~h}$ turned out to be quite similar. Thereafter, the intensity of the volatile compounds per- 
ceived by certain sensors increased as the fermentation progressed. This observation resulted from the influence of the bacterial development. On Figure 3, are displayed, as an example, the evolutions of the response of 9 sensors. The fermentation was carried out with the N1 starter mix, each bacterium being brought to the milk at equal levels (50/50). Two behaviours could be observed: sensors 3,4 and 5 increased from $t=2 \mathrm{~h}$ to $\mathrm{t}=24 \mathrm{~h}$-as a consequence of the bacterial growth-whereas the other sensors remained stable or slightly decreased. The scattering of the intensity responses into two groups could be generalized to the 64 sensors. It is noteworthy that the evolution of S3, S4 and S5 was strongly correlated with the increasing of the bacterial level and the diminution of the $\mathrm{pH}(\mathrm{r}>0.99 ; \mathrm{p}<0.05)$.

From these results, two consequences were deduced for the other experiments:

It is preferable to work with microfiltered milk, which avoid to subtract the profile of the heated milk

It is necessary to wait at least $3 \mathrm{~h}$ before observing a detectable influence of the bacteria. We decided to work with the results obtained after a $7 \mathrm{~h}$ delay.

\subsection{Use of NeOse Pro to Discriminate Milks Fermented Either with Streptococcus thermophilus or Lactobacillus delbrueckii subsp Bulgaricus}

Two samples of half skimmed microfiltered milk were fermented either with $S t$ thermophilus or with $L b$ delbrueckii subsp bulgaricus and analysed with the NeOse Pro apparatus. The radar charts of the two milks after a $7 \mathrm{~h}$ fermentation step appear on Figure 4. The results presented here correspond with the strains STN2 and LBN2, knowing that the study was also made with STN1 and LBN1. To the eyes, the shapes of the radar charts seem clearly different on the basis of the answer of the 64 sensors.

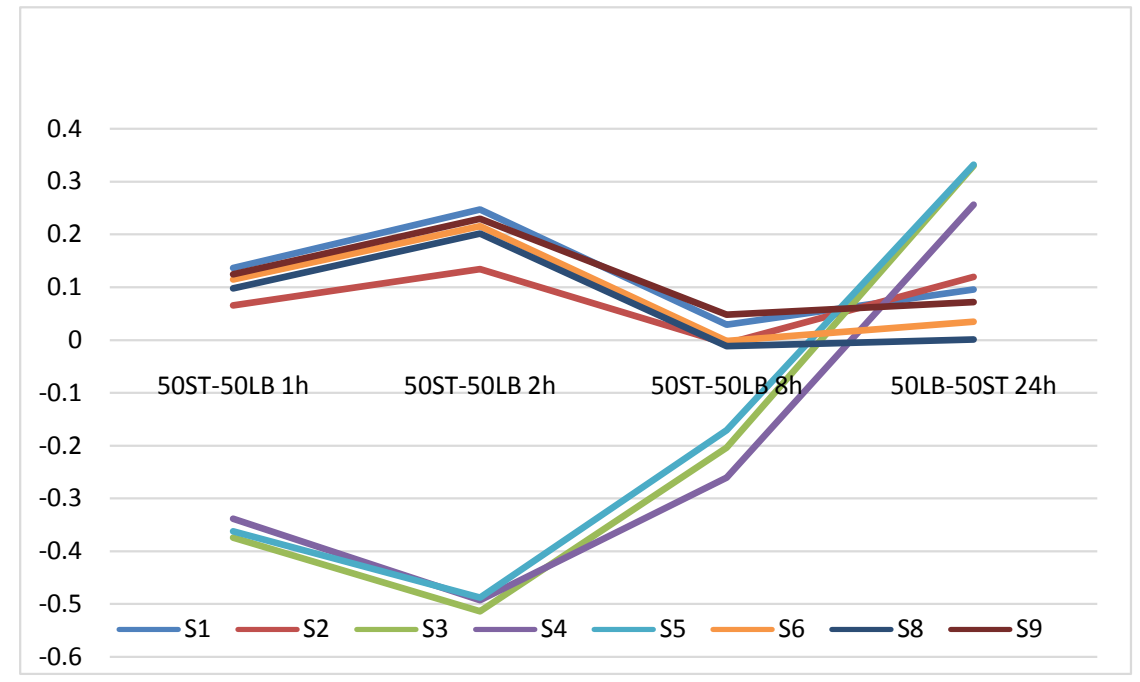

Figure 3. Evolution of the intensity response of 9 sensors (S\#) during the fermentation step of N1 starter with a ratio of LB/ST equal to 50/50. Data are expressed in units. 


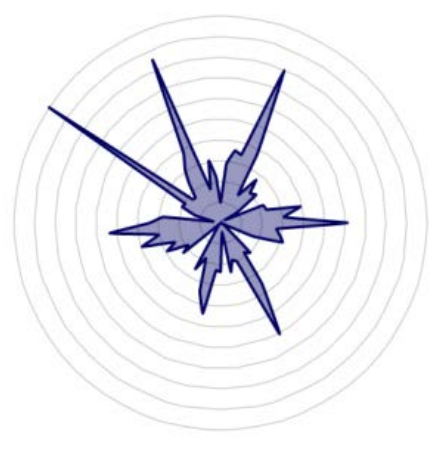

STN2

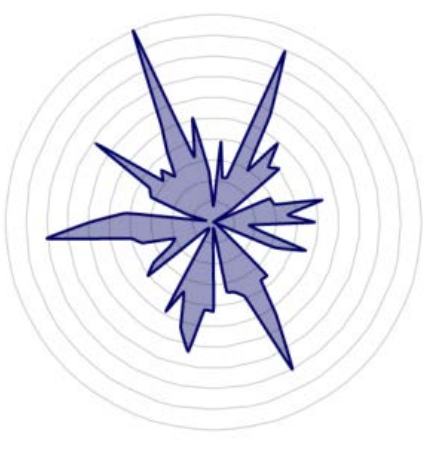

LBN2

Figure 4. Example of radar chart of two sample of milk fermented either with Lactobacillus delbrueckii subsp bulgaricus (LBN2) or Streptococcus thermophilus (STN2). The data were gathered after a $7 \mathrm{~h}$ culture step at $42^{\circ} \mathrm{C}$.

A principal component analysis was built (Figure 5). The first two axes of the PCA totalized $97.10 \%$ of the information inertia ( $82.95 \%$ for the first). The discrepancy was less evident than the difference observed between non-fermented and fermented milks. Overall, the scattering of the repetitions was more important. Nevertheless, the two groups appeared distinct. As waited, the same results were observed with STN1 and LBN1.

\subsection{Use of NeOse Pro to Discriminate the Two Yoghurt Mix}

Three cultures were made with the two yogurts mix N1 and N2 with the three theoretical bacterial ratios (ST/LB, 1/99, 50/50, 99/1). Experiments were made with microfiltered half skimmed milk. NeOse Pro data were obtained after a $7 \mathrm{~h}$ culture step. They were successively analysed by PCA (results not shown) and HCA (Figures 6(a)-(c)). The data were analysed separately since the discrepancy between the different ratios was not evident, as indicated later in the article. The two yogurt mix appeared clearly separated whatever the ratio considered. A REP-PCR was performed on the four bacterial strains. Figure 7 shows the agarose gel after staining. The four strains appeared clearly distinct, LB vs ST and STN1 vs STN2 or LBN1 vs LBN2. They were then supposed to lead to different results after fermentations steps.

\subsection{Sample Discrimination Based on Different Bacterial Ratios, Associated with GC/MS}

In this experiment, we compared the three different ratios ST/LB of the two mix; as previously, analyses were made at the end of the fermentation step (T7 h). A PCA followed by a HCA was performed on the NeOse Pro data, mix by mix. After $7 \mathrm{~h}$, the $\mathrm{pH}$ values and the TTA of the six cultures were respectively equal to $4.16 \pm 0.23$ and $69.6 \pm 6.77 \mathrm{~mL}$. The levels of the two microbial populations were also close, $1.70 .10^{8} \pm 2.33 .10^{8} \mathrm{cfu} / \mathrm{mL}$ for $\mathrm{LB}$ and $2.50 .10^{8} \pm 2.44 .10^{8} \mathrm{cfu} / \mathrm{mL}$, whatever the initial ratio or the mix. The NeOse Pro profiles were also similar (Figure 8). It was nearly impossible to separate the three ratios from the same mix. 
A GC/MS analysis was made after $7 \mathrm{~h}$ of fermentation on the fermented milk (two mix and three ratios) to characterize the chemical nature of the volatile compounds and to associate them with the results of the NeOse Pro analysis. 28 molecules were found at significant levels, among them the most important were: acetaldehyde, 2,3-butanedione, ethyl acetate, 3-hydroxy 2-butanone.

NeOse Pro data were crossed with the GC/MS results and analysed by PCA and CHA, the former being considered as the main parameters whereas the latter were just additive data (not shown).

Out of the 28 main molecules detected by GC/MC analysis, only one-acetaldehyde-was clearly linked with the same set of sensors, whatever the bacterial mix considered (Table 3). Acetaldehyde was detected by sensors C19, C13, C44 and C45. However, following the mix, some other sensors could be excited as well-C4, C14, C51, C6, C46 for N1; C39 for N2. For the other molecules, no clear relation was noticeable. For example, ethyl acetate, was linked to $\mathrm{C} 1$ to C12, C14 to C18, C20, C21, C24 to C31, C33 to C38, C40, C41, C43, C46 to C56 sensors, for N1, and C58 to C62 sensors for N2.

Table 3. Relation between acetaldehyde and the rank of the sensor activated. Captors in red rectangles are common to the two bacterial mix.

\begin{tabular}{ccccccc}
\hline Bacterial couple & compound & \multicolumn{4}{c}{ Sensor rank } \\
\cline { 2 - 4 } N1 & acetaldehyde & C4 & C6 C13 & C14 & C18 C19 C44 & C45 C46 C51 \\
N2 & acetaldehyde & & & C13 C19 & C39 & C44 C45 \\
\hline
\end{tabular}

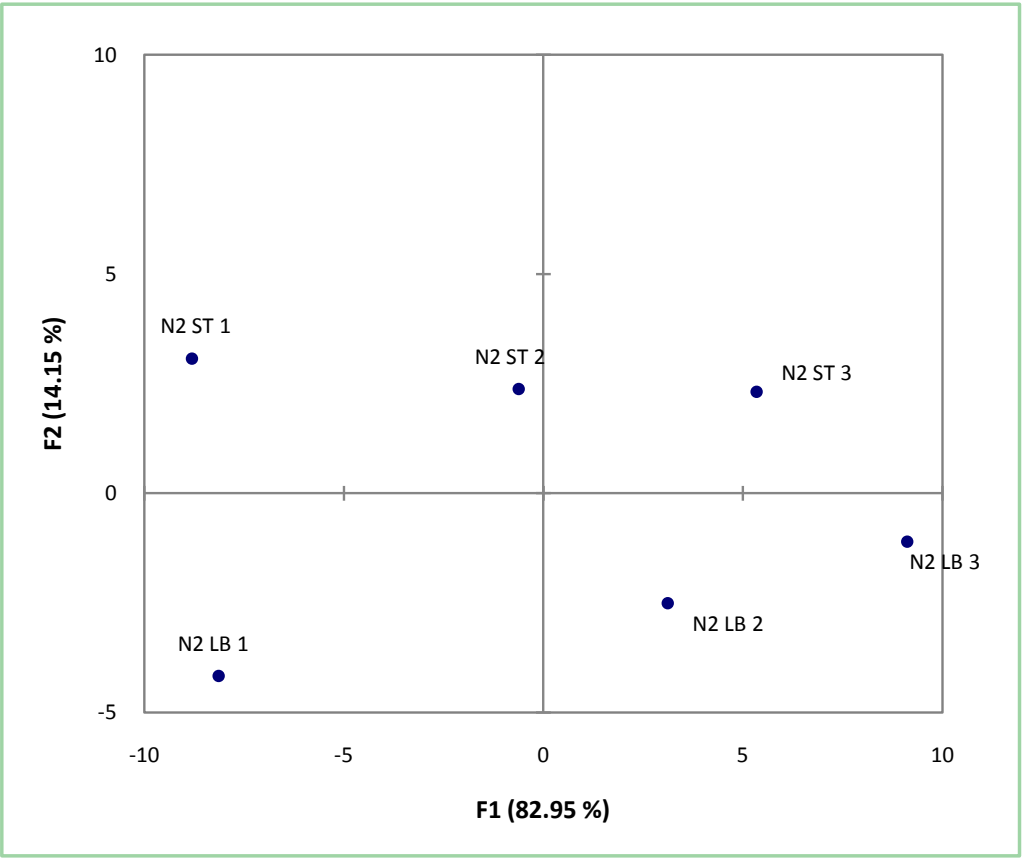

Figure 5. Principal Component Analysis (PCA) of NeOse Pro data obtained on milks fermented with Lactobacillus delbrueckii subsp bulgaricus (N2 LB) or Streptococcus thermophilus (N2 ST). Numbers in brackets refer to the different repetitions. 

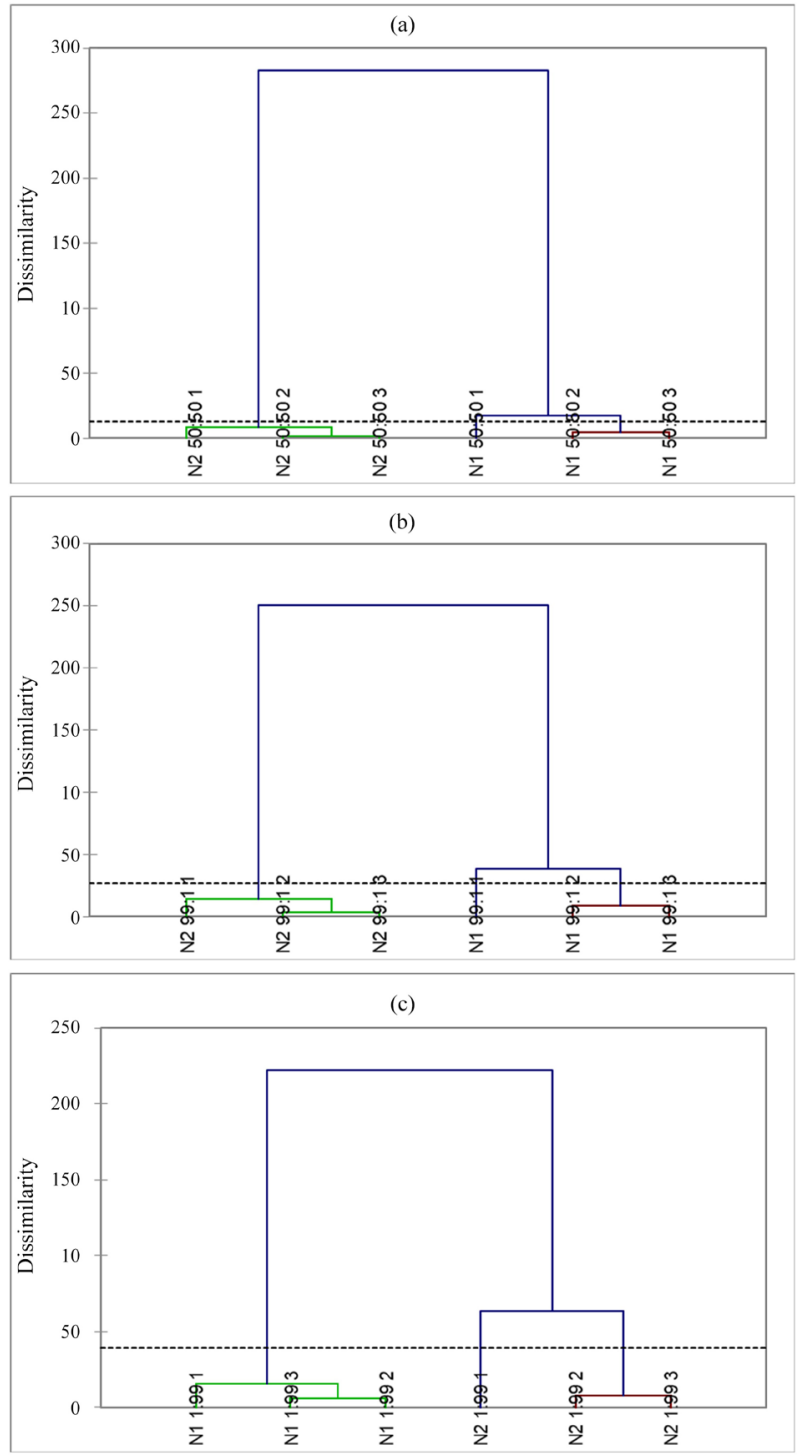

Figure 6. Hierarchical Cluster Analysis (HCA) obtained with the NeOse Pro data after Principal Component Analysis (PCA). Results were gotten after a $7 \mathrm{~h}$ fermentation step either with the bacterial mix N1 or N2. Three ratios (ST/LB) were 50:50, 99:1 and 1:99.

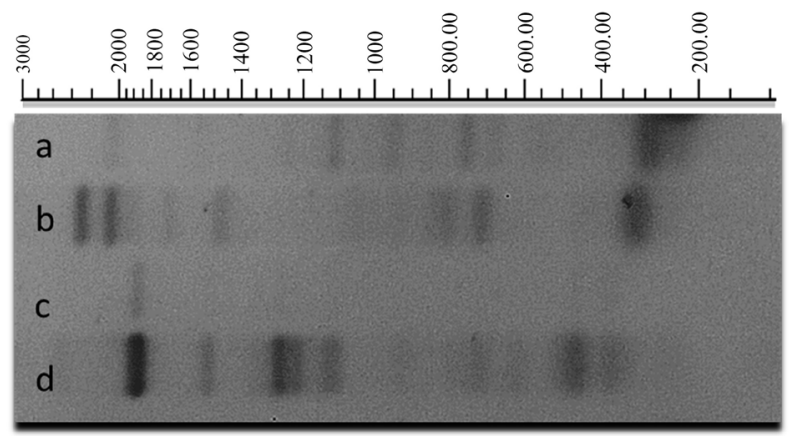

Figure 7. REP-PCR profiles obtained from each of the four bacterial strains LBN2 (a), LBN1 (b), STN2 (c), STN1 (d). The vertical scale, referring to the band size, is expressed in base pairs. 

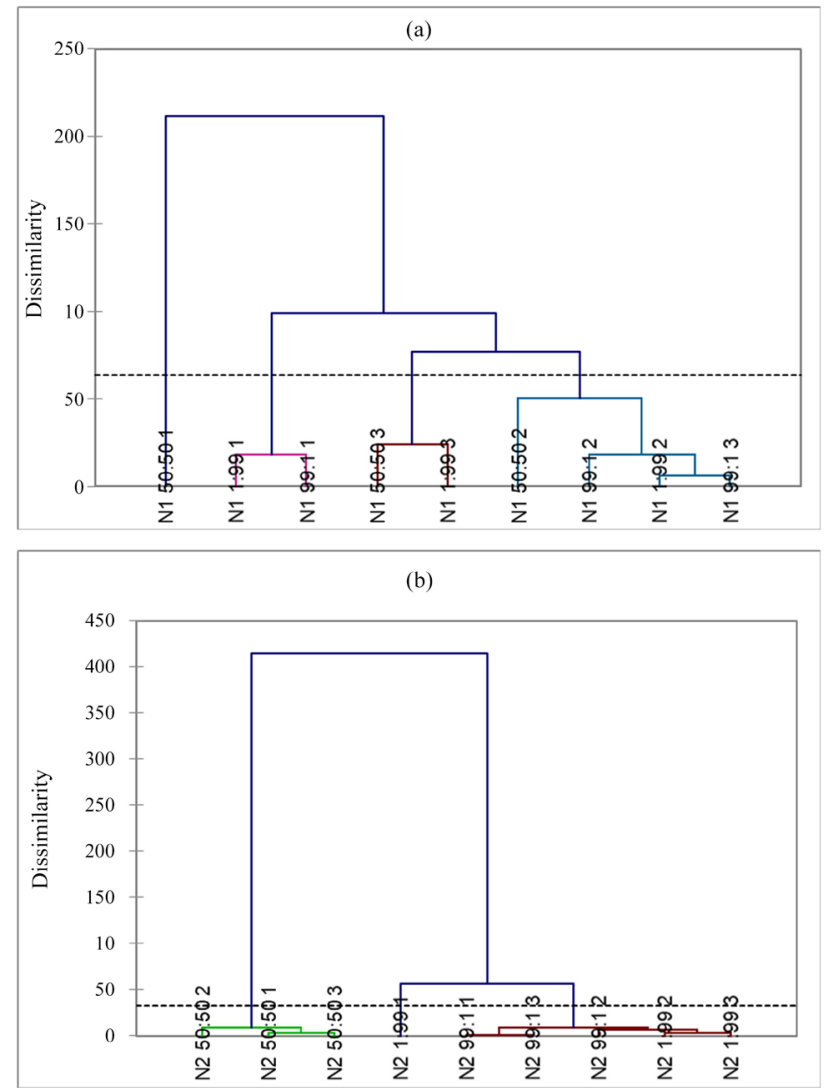

Figure 8. Hierarchical Cluster Analysis (HCA) obtained with the NeOse Pro data after Principal Component Analysis (PCA). Results were gotten after a $7 \mathrm{~h}$ fermentation step either with the bacterial mix $\mathrm{N} 1$ (a) or N2 (b). The three ratios (ST/LB) were 50:50 (a), 99:1 (b) and 1:99 (c). Numbers in brackets refer to the different repetitions.

\section{Discussion}

Tools available to control the correct evolution of fermented food rely generally on the monitoring of $\mathrm{pH}$, acidity and temperature. These parameters are mostly interesting because of their ease to use and the immediate results they propose. However, they encompass gross approximations which can appear in detail inappropriate to follow specific mechanisms. The case of $\mathrm{pH}$ is particularly typical. This measure corresponds with the accumulation of acid compounds (lactic acid for instance) during the fermentation step. But its deciphering needs to include the influence of the buffer capacity of the food matrix. As a consequence, new tools are needed to better describe fermentation dynamics, in parallel with classical approaches. The NeOse Pro apparatus is a portable tool developed to measure at once the aromatic profile of a product, either fermented or not. Volatile molecules are caught to give a photograph of the total aroma at a given time, qualitatively and quantitatively. However, at that time, little is known on the efficiency of NeOse Pro in hydrated products-yoghurt for instance. Also, no information is available to explain the profiles obtained. In this study, we tested the relevance of the NeOse Pro to discriminate three different bacterial ra- 
tios and two bacterial yogurt mix after a $7 \mathrm{~h}$ fermentation step.

Yogurts are fermented milk which result from the action of two microbes: Streptococcus thermophilus and Lactobacillus delbrueckii subsp. bulgaricus. After seeding, the milk is clotted under the exclusive action of these two bacteria. This change of state is explained by the synergistic action of the metabolisms of the two bacteria: streptococci start acidification and lactobacilli finish the fermentation step as the $\mathrm{pH}$ goes down. Such an interaction is called protocooperation [12]. No whey being removed, the product is strongly hydrated, which affects the aroma profile.

We tested the influence of the heating of the milk $\left(110^{\circ} \mathrm{C}-10 \mathrm{~min}\right)$ on the evolution of the NeOse Pro profiles. Yoghurts are made with heated milk, even if the temperature applied is generally less intense $\left(>90^{\circ} \mathrm{C}, 2-4 \mathrm{~min}\right)$. And it is well known that temperature modify more or less the aromatic profile of the milk following the intensity [13]. It was confirmed in our case. The heat treatment of the milk led to the appearance of a great deal of volatile molecules which created a background noise hiding the effect of the bacteria during the fermentation step. This observation implied the subtraction of the heated milk profile before any further analyse. In the case of the document, we preferred to use microfiltered milk.

We evaluated the NeOse Pro capacity to discriminate milk from yoghurt. The aromatic profiles collected proved to be completely dissimilar. The differences observed are explained by the metabolism of Lb bulgaricus and St thermophilus, which led to the production of aromatic molecules. This result is convenient with the observation of Wilson and Baietto (2009) [14]. According to them, electronic noses can be used for quality and processing controls.

We tested the discrimination capability of the NeOse Pro apparatus after a $7 \mathrm{~h}$ fermentation step, made either with Lb bulgaricus or St thermophilus. We noted that it was necessary to wait a minimum duration of $3 \mathrm{~h}$ to observe significant modifications of the profiles. Thereafter, the fermentation delay was chosen so as to be sure to be under $\mathrm{pH} 4.5 ; 7 \mathrm{~h}$ proved to be appropriate. The discrepancy between the two LAB has been established for a long time. The major discriminant features cover the shape (bacilli vs cocci), the acid resistance, or the production of DL lactic acid or just L lactic acid. In addition, St thermophilus is known to secrete high exopolysaccharide (EPS) quantities and is able to use citric acid and to produce diacetyl and acetaldehyde from threonine [15]; whereas Lb bulgaricus releases mainly lactic acid, lesser quantities of EPS. The results we obtained were slightly different between the two genera, and less important than awaited. Several reasons can be put forward to explain these observations. Even if St thermophilus is able to metabolize citric acid, this metabolism can lead to three different final products. Diacetyl and acetoin exhibit strong aroma whereas 2,3 butanediol is generally odour less. Following the redox potential of the environment, the citrate metabolism is oriented towards diacetyl or acetoin or 2,3 butanediol [16]. During the course of our experiments, the redox potential was neither controlled nor adjusted. If some diacetyl was measured (2,3 buta- 
nedione), quantities were perhaps too low to be significant. It was also difficult to link the results obtained with the NeOse Pro and the GC/MS. Among the 28 molecules identified by chromatography, only one, acetaldehyde, corresponded with the same sensors (C13, C19, C44 and C45) whatever the experiment made. In a future work, it could be interesting to blend some pure molecules in a lactic gel to confirm or not these observations and to extend them to other captors and other molecules [17] [18] [19].

In the course of our experiments, we intended to distinguish two bacterial yogurt mix (N1, N2), including different ratios (\%) of streptococci and lactobacilli $(1 / 99,50 / 50,99 / 1)$. The REP-PCR profiles of the four strains were clearly different justifying the interest for these two mixes. However, it is assumed that such an observation does not necessary involve any metabolic differences [20]. Different NeOse Pro profiles were clearly observed, whatever the ratio or the mix considered. But from an experiment to the following, the discrepancy differed, indicating that the use of NeOse Pro can fail to separate different bacterial ratios. Different explanations can be put forward. First, we decided to analyse the aromatic profiles after a $7 \mathrm{~h}$ delay. However, at that time initial differences disappeared: the two bacteria were at the same levels (close to 50/50) and consequently the corresponding $\mathrm{pH}$ and acidities of the media (respectively around 4.1 and $70 \mathrm{~mL}$ of $\mathrm{NaOH} 0.1 \mathrm{M}$ ). Also, the development of the two microbes is closely linked. $\mathrm{Lb}$ bulgaricus contributes to release of many small peptides and free amino acids in the medium which favour the growth of Streptococcus. In return, Streptococcus produces formic acid, a compound essential for the synthesis of the nucleic acids of Lactobacillus. But, the microbes can also interact negatively through their respective production of lactic acid [12]. As a consequence, the change in the initial bacterial ratio leads to a loss of balance in the delicate alchemy of the yogurt making, which can explain these partially erratic results. Such an observation is not necessarily surprising. St thermophilus has to be more efficient than Lactobacillus at the beginning of the fermented step. Streptococcus being less tolerant to acid conditions, a late growth is supposed to favour Lactobacillus. As a consequence, the dynamic of aroma production will be changed. At that time, we can argue that NeOse Pro could be used as a control tool, in parallel with the following of $\mathrm{pH}$ or acidity, and to discriminate different bacterial mix. Further analyses have to be made on other bacterial mix. The use of this apparatus to separate mix on their bacterial ratios is conceivable. But it requires new experiments.

To bypass this problem, we propose to make a dynamic monitoring of the aromatic profile with the NeOse Pro during the whole fermentation step (and not only from time to time). Such a procedure will probably allow us to identify the different phases of volatile molecule production.

\section{Conclusion}

NeOse Pro is a new analytical tool developed to mimic the functioning of the nose during the odour perception. This small apparatus is portable so as to allow 
technicians direct measures, for instance during the food making. In this work, we tested the efficiency of NeOse Pro in a hydrated product, the yoghurt. It was observed that the fermentation step induced detectable aromatic modifications of the initial milk, especially after a minimum fermentation delay $(3 \mathrm{~h})$. The discrepancy ability of NeOse Pro differed following the test made and the treatment of the milk. Two bacterial mix containing different bacterial strains were clearly separated from each other. However, this separation was less evident when the ratios changed. Right now, only one molecule was associated with some of the sensors of the apparatus. In the future, we plan to test the addition of pure "yoghurt" molecules in a lactic gel. We are convinced that NeOse Pro will find its place as a controlled tool during the fermentation processes. However, new experiments have to be done to enforce these first data.

\section{Acknowledgements}

This work was partially supported by the NEOSE F3 PIA3 project (France Agrimer), and the OBP-Optinose project (ANR-18-CE42-0012). We also thank the support of the Agri-Food Innovation Cluster Vitagora.

\section{Conflicts of Interest}

The authors declare no conflicts of interest regarding the publication of this paper.

\section{References}

[1] Fisberg, M. and Machado, R. (2015) History of Yogurt and Current Patterns of Consumption. Nutrition Review, 73, 4-7.

[2] Heller, K.J. (2001) Probiotic Bacteria in Fermented Foods: Product Characteristics and Starter Organisms. American Journal of Clinical Nutrition, 73, 374s-379s.

[3] O’Sullivan, M.G., Thornton, G., O’Sullivan, G.C. and Collins, J.K. (1992) Probiotic Bacteria: Myth or Reality? Trends in Food Science and Technology, 3, 309-314. https://doi.org/10.1016/S0924-2244(10)80018-4

[4] Lourens-Hattingh, A. and Viljoen, B.C. (2001) Yogurt as Probiotic Carrier Food. International Dairy Journal, 11, 1-17. https://doi.org/10.1016/S0958-6946(01)00036-X

[5] Zourari, A., Accolas, J.P. and Desmazeaud, M.J. (1992) Metabolism and Biochemical Characteristics of Yogurt Bacteria. A review. Lait, 72, 1-34. https://doi.org/10.1051/lait:199211

[6] Demarigny, Y., Juillard, V., Deschamps, N. and Richard, J. (1994) Comparison of 3 Methods for the Kinetic Study of Milk Acidification by Strains of Lactococcus Lactis. Proposal of the "Vmar" Concept. Lait, 74, 23-32. https://doi.org/10.1051/lait:199413

[7] Rizzello, C.G., Coda, R., Wang, Y., Verni, M., Kajala, I., Katina, K. and Laitila, A. (2018) Characterization of Indigenous Pediococcus pentosaceus, Leuconostoc kimchii, Weissella cibaria and Weissella confusa for Faba Bean Bioprocessing. International Journal of Food Microbiology, 302, 24-34. https://doi.org/10.1016/j.ijfoodmicro.2018.08.014

[8] Aggelopoulos, T., Katsieris, K., Bekatorou, A., Pandey, A., Banat, I.M. and Koutinas, 
A. (2014) Solid State Fermentation of Food Waste Mixtures for Single Cell Protein, Aroma Volatiles and Fat Production. Food Chemistry, 145, 710-716. https://doi.org/10.1016/j.foodchem.2013.07.105

[9] Maho, P. (2020) Reliable Chiral Recognition with an Optoelectronic Nose Biosensors. Bioelectronics, 159, Article ID: 112183. https://doi.org/10.1016/j.bios.2020.112183

[10] Slimani, S., Bultel, E., Cubizolle, T., Herrier, C., Rousselle, T. and Livache, T. (2020) Opto-Electronic Nose Coupled to a Silicon Micro Pre-Concentrator Device for Selective Sensing of Flavored Waters. Chemosensors, 8, Article No. 60. https://doi.org/10.3390/chemosensors8030060

[11] Masco, L., Huys, G., Gevers, D., Verbrugghen, L. and Swings, J. (2003) Identification of Bifidobacterium Species Using Rep-PCR Fingerprinting. Systematic and Applied Microbiology, 26, 557-563. https://doi.org/10.1078/072320203770865864

[12] Atlan, D., Béal, C., Champomier-Vergès, M.-C., Chapot-Chartier, M.-P., Chouayekh, H., Cocaign-Bousquet, M., Deghorain, M., et al. (2008) Métabolisme et Ingénierie Métabolique. In: Corrieu, G., Luquet, F.-M., Eds., Bactéries lactiques, de la Génétique aux Ferments, Vol. 2008, Tec\&Doc, Paris, 271-449.

[13] Perreault, V., Britten, M., Turgeon, S.L., Seuvre, A.M., Cayot, P. and Voilley, A. (2010) Effects of Heat Treatment and Acid-Induced Gelation on Aroma Release from Flavoured Skim Milk. Food Chemistry, 118, 90-95. https://doi.org/10.1016/j.foodchem.2009.04.095

[14] Wilson, A.D. and Baietto, M. (2009) Applications and Advances in Electronic-Nose Technologies. Sensors, 9, 5099-5148. https://doi.org/10.3390/s90705099

[15] Monnet, C., Latrille, E., Béal, C. and Corrieu, G. (2008) Croissance et Propriétés Fonctionnelles des Bactéries Lactiques. In: Corrieu, G. and François-Marie, L., Eds., Les Bactéries Lactiques, de la Génétique aux Ferments, Vol. 2008, Tec\&Doc, Paris, 512-594.

[16] Fox, P.F., McSweeney, P.L.H., Cogan, T.M. and Guinee, T.P. (2004) Cheese: Chemistry, Physics and Microbiology, Volume 1: General Aspects. Elsevier, London.

[17] Ott, A., Fay, L.B. and Chaintreau, A. (1997) Determination and Origin of the Aroma Impact Compounds of Yoghurt Flavor. Journal of Agricultural and Food Chemistry, 45, 850-858. https://doi.org/10.1021/jf960508e

[18] Toso, B., Procida, G. and Stefanon, B. (2002) Determination of Volatile Compounds in Cows' Milk Using Headspace GC-MS. Journal of Dairy Research, 69, 569-577. https://doi.org/10.1017/S0022029902005782

[19] Imhof, R. and Bosset, J.O. (1994) Quantitative GC-MS Analysis of Volatile Flavour Compounds in Pasteurized Milk and Fermented Milk Products Applying a Standard Addition Method. LWT-Food Science and Technology, 27, 265-269. https://doi.org/10.1006/fstl.1994.1053

[20] Demarigny, Y., Dalmasso, M., Tonleu, A., Rigobello, V., Beuvier, E., Ly-Chatain, M.H. and Bouton, Y. (2011) Influence of the Backslopping Practice on the Microbial Diversity of the Lactococcus Population in a Model Cheesemaking. Food and Nutrition Science, 2, 618-627. http://dx.doi.org/10.4236/fns.2011.26087 